\title{
The effect of oil palm decanter cake on the accumulation of nutrients and the stomatal opening of Solanum melongena (brinjal) plants
}

\author{
Asha Embrandiri ${ }^{1} \cdot$ Parveen Fatemeh Rupani $^{1} \cdot$ Sultan Ahmed Ismail ${ }^{2}$ • \\ Rajeev Pratap Singh ${ }^{3}$ M. Hakimi Ibrahim ${ }^{1} \cdot$ Mohd. Omar b. Abd. Kadir ${ }^{1}$
}

Received: 24 June 2015/Accepted: 28 March 2016/Published online: 30 April 2016

(c) The Author(s) 2016. This article is published with open access at Springerlink.com

\begin{abstract}
Purpose Research has shown that oil palm decanter cake (DC) serves as a potential source of nutrients for plant growth. This study therefore investigated the applicability of decanter cake (DC) as an amendment to soil for the growth of Solanum melongena (brinjal) at three ratios 10 , 20, $30 \%$ DC and suitable controls $(0 \%)$.

Methods Seeds of brinjal were sown in soils amended with decanter cake at 10,20,30\% w/w and $0 \%$ as control. Nutrient enrichment factors were calculated from the concentration of selected metals $(\mathrm{Cu}, \mathrm{Ca}, \mathrm{Fe}, \mathrm{Zn}$ and $\mathrm{Mg}$ ) in plant parts. The scanning electron micrographs were also taken to measure the stomatal opening/closing due to the effect of excess nutrients on the leaf structure.

Results Enrichment factor (EF) values in this study were all below 3 indicating low enrichment of metal ions from soil to plants. SEM studies of the leaf epidermis of the test plants revealed the closure of guard cells with increasing decanter cake treatments.

Conclusions Decanter cake at $20 \%$ amendments with soil could serve as a source of soil amendment for cultivation of $S$. melongena plants.
\end{abstract}

Keywords Palm waste $\cdot$ Decanter cake $\cdot$ Scanning electron micrographs $\cdot$ Enrichment factor $\cdot$ Brinjal

Asha Embrandiri

ashanty66@gmail.com

1 School of Industrial Technology, Universiti Sains Malaysia, 11800 Pulau Pinang, Malaysia

2 Ecoscience Research Foundation, 98, Baaz Nagar, 3/621, East Coast Road, Palavakam, Chennai 600041, India

3 Institute of Environment and Sustainable Development, Banaras Hindu University, Varanasi 221005, India

\section{Introduction}

The Malaysian palm oil industry is a major revenue earner (around USD 7 billion per annum in GDP) (Lim et al. 2015) and is ranked as one of the largest producers in the world. However, growth of the industry is synonymous with massive production of agro-industrial wastes (Liew et al. 2015). Zwart (2013) also stated that crude palm oil (CPO) production reached 18.91 million metric tons in 2011. Wastes such as palm oil mill effluent (POME), palm kernel cake (PKC), decanter cake (DC), empty fruit bunches (EFB), palm kernel shell (PKS), palm press fibre (PPF) are some of the major by-products of the palm mill (Singh et al. 2012). The easiest way to dispose oil palm solid wastes is by burning, so that the wastes could be reused for steam or power generation at the palm oil mills (Lim et al. 2015), while the most typical disposal option for the effluent is through ponding system (Lim et al. 2014).

The management of these poses a big challenge for the palm oil producing nations (Singh et al. 2012). Embrandiri et al. (2015) reported a number of on-going experiments utilising these by-products in various industries such as bio-fuels, lumber for wood, feed for animals, shells as activated carbon for water purification etc. Likewise, there are many studies reporting the use of organic wastes from agriculture for plant growth experiments. Olive waste extract at 10,30 and 50\% amendment ratios improved seed emergence of lettuce with reduced biomass (Kelepsei et al. 2009). Also, combinations of poultry manure and NPK resulted in significant differences in height and yield of spinach (Ndaeyo et al. 2013). Another example is the use of palm boiler ash for the growth of eggplant, okra and pepper (Adjei-Nsiah and Obeng. 2013). However, very few investigations have been carried out with regards to using decanter cake for the growth of vegetables with the 
exception of our previous study on lady's finger plants (Embrandiri et al. 2013). Therefore this work contributes to knowledge on the employment of decanter cake for the growth of brinjal plants in Malaysia.

Due to the foreseen increase in oil palm acreage in the years ahead, it is eminent that serious measures have to be taken to ensure the proper management of decanter cake to address the growing environmental concerns. The aim of the present research was to investigate the feasibility of using decanter cake in different combinations $(10,20,30 \% \mathrm{w} / \mathrm{w}$ ratio) with soil on the growth of Solanum melongena (brinjal) plants. Estimation of enrichment factors and scanning microscopic studies were carried to understand the accumulation pattern in shoots and leaves of experimental plant under the different decanter cake ratios. This would in the long run contribute to waste reuse and minimization strategies as nutrients are recycled back into the pedosphere.

\section{Methodology}

\section{Study site}

The studies were conducted at the nursery of Universiti Sains Malaysia, Penang from November 2011 to May 2012. Penang $\left(5^{\circ} 24^{\prime} 0^{\prime \prime} \mathrm{N}\right.$ : $\left.100^{\circ} 14^{\prime} 0^{\prime \prime} \mathrm{E}\right)$ has a relative humidity of $70-90 \%$. The average nursery temperature ranged between 30 and $35{ }^{\circ} \mathrm{C}$. Analysis of fresh decanter cake has been provided in Table 1 .

\section{Sample collection}

Fresh decanter cake obtained from Malpom Industries Sdn Bhd, Nibong Tebal, Penang, Malaysia was dried in a blow

Table 1 Analysis of fresh decanter cake

\begin{tabular}{lr}
\hline Parameters & \multicolumn{1}{l}{ Value } \\
\hline $\mathrm{pH}$ & $4.40 \pm 0.01$ \\
$\mathrm{EC}\left(\mathrm{mScm}^{-1}\right)$ & $2.96 \pm 0.02$ \\
$\mathrm{Cd}\left(\mathrm{mg} \mathrm{g}^{-1}\right)$ & $0.05 \pm 0.01$ \\
$\mathrm{~Pb}\left(\mathrm{mg} \mathrm{g}^{-1}\right)$ & $0.56 \pm 0.03$ \\
$\mathrm{Ni}\left(\mathrm{mg} \mathrm{g}^{-1}\right)$ & $0.63 \pm 0.02$ \\
$\mathrm{Cu}\left(\mathrm{mg} \mathrm{g}^{-1}\right)$ & $0.81 \pm 0.04$ \\
$\mathrm{Fe}\left(\mathrm{mg} \mathrm{g}^{-1}\right)$ & $0.46 \pm 0.02$ \\
$\mathrm{Ca}\left(\mathrm{mg} \mathrm{g}^{-1}\right)$ & $0.35 \pm 0.02$ \\
$\mathrm{Mg}\left(\mathrm{mg} \mathrm{g}^{-1}\right)$ & $0.012 \pm 0.03$ \\
$\mathrm{~N}(\%)$ & $6.52 \pm 0.03$ \\
$\mathrm{~K}\left(\mathrm{mg} \mathrm{g}^{-1}\right)$ & $0.07 \pm 0.02$ \\
Organic carbon $(\%)$ & $74.4 \pm 0.02$ \\
$\mathrm{C}: \mathrm{N} \mathrm{ratio}$ & $11.4 \pm 0.02$ \\
$\mathrm{Bulk} \mathrm{density}\left(\mathrm{g} \mathrm{cm}^{-3}\right)$ & $0.57 \pm 0.04$ \\
\hline
\end{tabular}

drier at $60{ }^{\circ} \mathrm{C}$, powdered and sieved with a $2 \mathrm{~mm}$ sieve. Soil samples were collected at a depth of $10 \mathrm{~cm}$ also from Nibong Tebal area, Penang. It was air dried, homogenized and passed through a $2 \mathrm{~mm}$ sieve for further processing.

\section{Sampling of plants}

Three plant samples from each treatment were randomly harvested for different analyses at 60 and 90 days respectively, chosen based on previous studies. Plants with intact roots were carefully uprooted from the replicate treatments and thoroughly washed under running water on a $1 \mathrm{~mm}$ mesh sieve to remove the soil particles adhering to the roots (Singh and Agrawal 2009) Measurements were taken for the different growth parameters and sample preparation.

\section{Experimental setup}

The experiments consisted of planter pots of $15 \mathrm{~cm} \times 15 \mathrm{~cm}$ with $3 \mathrm{~kg}$ of amended soils as reported by Ekutudo et al. (2011) arranged in completely randomized designs. Amendments (0\% (control), 10, 20 and $30 \% \mathrm{w} / \mathrm{w}$ DC) were prepared homogenously and filled into pots. Identical water regime $(10-15 \mathrm{ml})$ was maintained and pots left for 15-20 days of stabilization (Singh 2008). Prior to sowing, seeds of brinjal were soaked in distilled water for $3 \mathrm{~min}$ to enhance germination. About 10 seeds per treatment were sown manually at equidistant positions. After germination, the plants were thinned to 3 per pot and identical temperature and humidity conditions were maintained throughout the growth period.

\section{Measurement of data}

Uptake and distribution of metals in different plant parts

The uptake and distribution of metals $(\mathrm{Cu}, \mathrm{Ca}, \mathrm{Fe}, \mathrm{Zn}$ and $\mathrm{Mg}$ ) in different plants was determined by the enrichment factors. The enrichment factor (EF) was calculated to derive the degree of metal accumulation in plants in treated soils with respect to plants growing in control soil (Kisku et al. 2000). Metals were estimated prior to the calculation by the AAS using the wet digestion method (Allen et al. 1986)

$\mathrm{EF}=\frac{\text { Concentration of metals in plant parts at different treatments }}{\text { Concentration of metals in plant parts in control }}$

Scanning electron micrographs of leaf epidermis of brinjal plants grown in DC amended soils

The HMDS (hexamethyldisilazane) technique was employed for the SEM studies (Nation 1983). Leaf 
samples were plucked and cut into small $1 \times 1 \mathrm{~cm}$ squares, fixed in McDowell trump fixative at $4{ }^{\circ} \mathrm{C}$ and stored for preparation. The samples were then washed in $0.1 \mathrm{M}$ phosphate buffer 3 times for $10 \mathrm{~min}$ each thereafter post-fixed in $1 \%$ Osmium tetra oxide for $1-2 \mathrm{~h}$ at room temperature. The leaves thereafter were washed in distilled water twice for $10 \mathrm{~min}$ each. Subsequent dehydration followed in the following order; 50, 75, 95 and $100 \%$ ethanol for 15, 15, 15 (twice), and 20 (thrice) minutes respectively. Dehydrated tissues were then immersed in $2 \mathrm{ml}$ of HMDS for another $10 \mathrm{~min}$. The HMDS was then decanted and the vials with the leaf tissues were left in the desiccators to dry at room temperature. The dried samples were mounted onto the SEM specimen stub and coated with gold dust. Each sample was viewed at $2000 \times$ magnifications. The average stomatal openings of the leaf epidermis of brinjal subjected to the DC treatments were also calculated.

\section{Statistical analysis}

Data was subjected to one way ANOVA test to assess the effect of each treatment on the respective parameters of the different test plants. Duncan's multiple range tests (DMRT) were also performed for parameters to test the significant difference between different treatments at $p=0.05$. All statistical analyses were performed using SPSS 16 software.
Fig. 1 a-c Enrichment factors of $\mathrm{Cu}, \mathrm{Zn}, \mathrm{Fe}$ in leaf (L) and shoot (S) portions of brinjal plants at different DC amendment ratios. Different letters in each group show significant difference at $p<0.05$
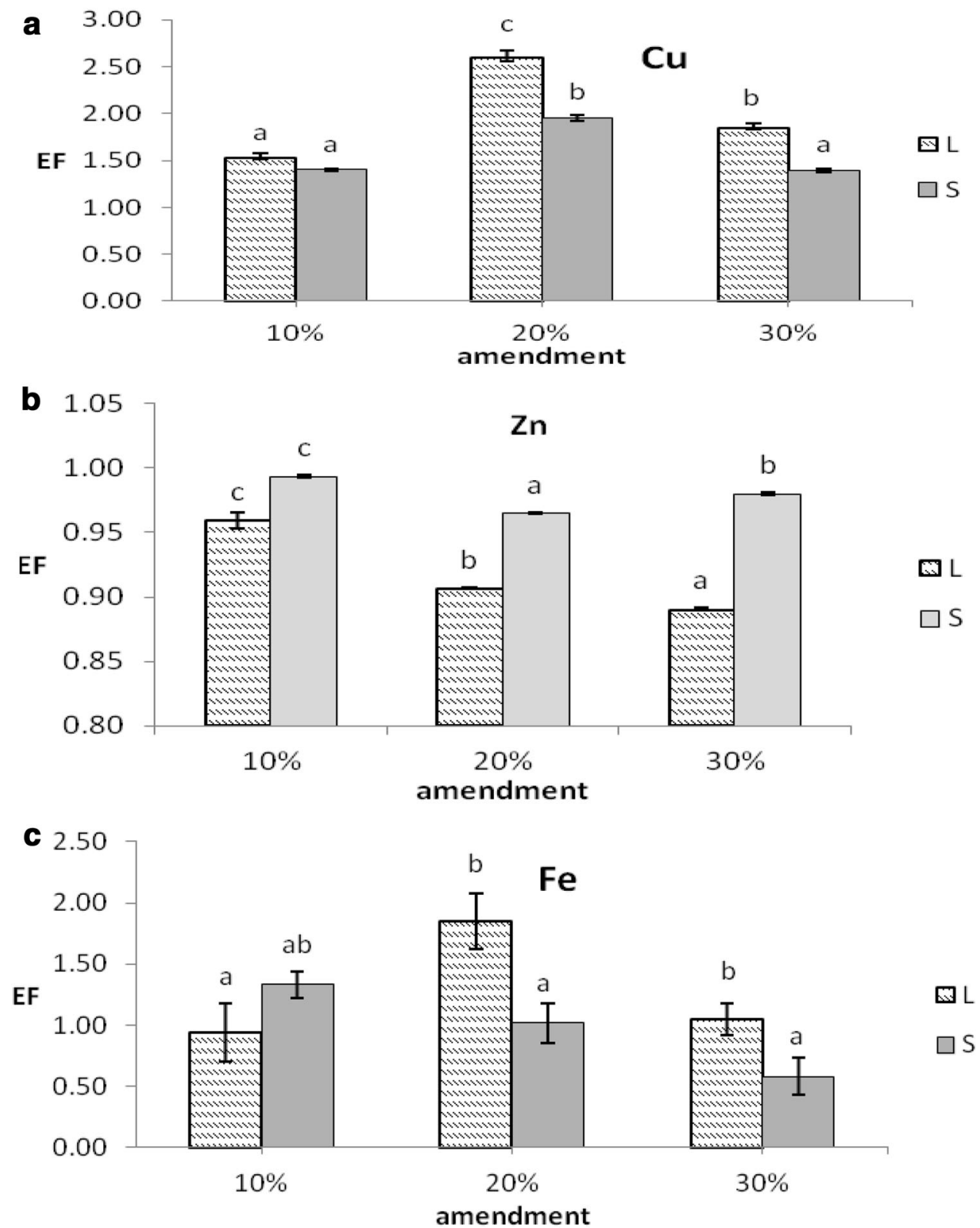
Fig. 2 a, b Enrichment factors of $\mathrm{Ca} \& \mathrm{Mg}$ in leaf $(\mathrm{L})$ and shoot (S) portions of brinjal plants at different DC amendment ratios. Different letters in each group show significant difference at $p<0.05$
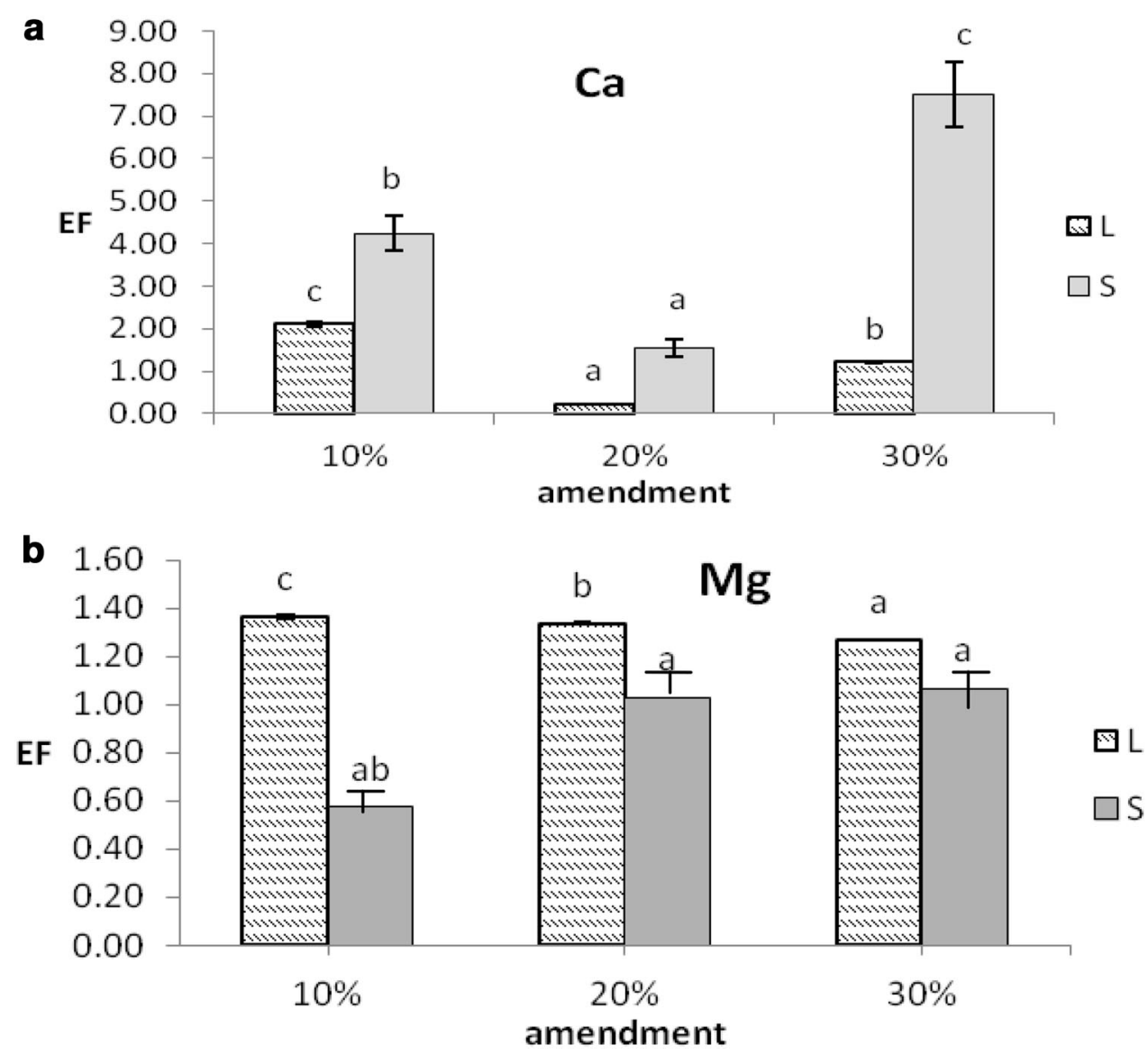

\section{Results and discussion}

Plants have the capability to accumulate metals when grown on soil with excess nutrients (Singh et al. 2010). The accumulation of metal ions by plants depends on a number of reasons such as soil physicochemical properties, plant species, climatic factors and chemical speciation of metals (Alloway et al. 1991). The enrichment factors (EF) of selected metals in plant parts under different DC treatments have been presented in Fig. 1 and 2. EF is calculated in order to establish the degree of soil contamination and heavy metal accumulation. It is the ratio between the concentration of metals in contaminated soil and the concentration of metals in uncontaminated soils (Mehes-Smith et al. 2013).EF of $\mathrm{Cu}$ in leaf portions was in the trend $20>30>10 \%$ while in the shoots the trend was $20>10>30 \%$ (Fig. 1). The lowest value recorded was at shoots grown on $30 \% \mathrm{DC}(1.50)$. $\mathrm{Zn}_{\mathrm{EF}}$ was highest in the leaves and shoots at $30 \%$ DC amendments $(0.89 \pm 0.01$ and $0.98 \pm 0.01$ respectively (Fig. 1). Both in the leaves and shoots the values varied significantly from each other $(p=0.02)$. Enrichment factors of $\mathrm{Fe}$ were $0.94 \pm 0.02,1.85 \pm 0.02$ and $1.05 \pm 0.02$ for 10,20 and $30 \%$ in leaves and 1.33, 1.02 and 0.58 in the shoots of the respective amendments (Fig. 1). Similar studies by Lorestani et al. (2011) on some native plants in Iran showed the plants had $\mathrm{EF}$ values of $\mathrm{Cu}, \mathrm{Zn}$ and $\mathrm{Fe}$ below 3. The Enrichment factors of $\mathrm{Cu}$ as indicators of uptake in spinach and carrots grown on sludge amended luvisol showed that $\mathrm{Cu} \mathrm{EF}$ in soil increased with sludge applications (Ngole 2011) which is not the case in this study. With regards to Magnesium, the EF values of the shoots varied significantly from each other. For $\mathrm{Ca}$, maximum $\mathrm{EF}$ was at $30 \%$ shoots $(7.51 \pm 0.13)$ and lowest at its leaves $(0.22 \pm 0.14)$. Thus in Brinjal plants, there was high enrichment of Ca only as all other metals fell below 3. This is explained by the high concentration of $\mathrm{Ca}$ in the initial DC analysis (Table 1). Table 2 presents the correlation coefficients $(r)$ between increasing DC rates and

Table 2 Correlation coefficient $(r)$ between selected enrichment factors in test plant and the addition of decanter cake

\begin{tabular}{lc}
\hline $\mathrm{EF}$ & $r$ values \\
\hline $\mathrm{Cu}$ & -0.349 \\
$\mathrm{Ni}$ & $-0.477^{*}$ \\
$\mathrm{Mg}$ & $-0.563^{*}$ \\
$\mathrm{Zn}$ & $0.494^{*}$ \\
$\mathrm{Ca}$ & $0.678^{*}$ \\
$\mathrm{Fe}$ & -0.375 \\
\hline * Correlation is & significant at \\
0.05 & \\
$* *$ Significant at the & 0.01 level \\
(2-tailed) &
\end{tabular}


metals in brinjal plants. From the table we see that $\mathrm{Ca}_{\mathrm{EF}}$ had strong positive correlation $\left(0.678^{* *}\right.$ at $\left.p<0.01\right)$. For $\mathrm{Cu}_{\mathrm{EF}}$ and $\mathrm{Fe}_{\mathrm{EF}}$, the values were negative and not significant. $\mathrm{EF}$ of
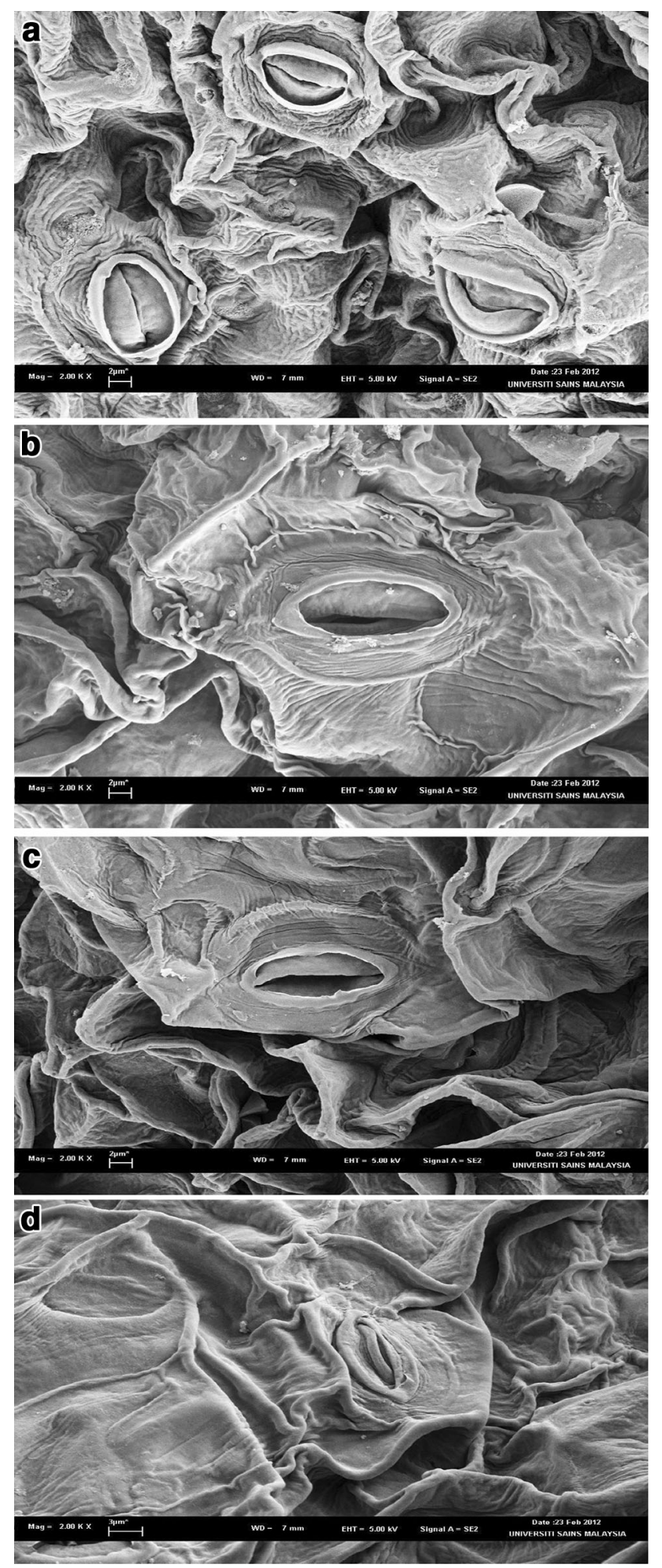

Fig. 3 SEM images (2000X magnifications) of the leaf epidermis of brinjal plants grown in $0 \%(\mathbf{a}), 10 \%(\mathbf{b}), 20 \%(\mathbf{c})$ and $30 \%(\mathbf{d}) \mathrm{DC}$
$\mathrm{Mg}$ had significant negative correlations at $p<0.05$ $(-0.563)$ while $\mathrm{Zn}$ EF showed positive correlations at $p<0.05$. It is thus evident that there is no accumulation of the metals in the plant parts thereby rendering the fruits safe for consumption. The physiology of brinjal plants is such that more nutrients are needed by other portions of the plant and not the roots or the leaves thus explaining the reason why there was higher concentration of $\mathrm{Ca}$ in the shoot portions than the leaves.

Guard cells are capable of integrating and responding rapidly to a number of physiological and abiotic stimuli (Assmann and Wang, 2001). Therefore, scanning electron microscopic studies (SEM) have become a popular model for exploring plant response to changing environmental conditions (Assmann and Wang, 2001). Closure of the stomata is regarded an ecological adaptation to protect plants against pollution damage (Ciamporova and Mistrik 1993). Scanning Electron Micrographs in this study indicated that at $10 \%$ the stomata of the leaf were almost identical to the control plants (Fig. 3b), at $20 \%$ DC the stomata open up and at $30 \%$ DC reduced in the leaf epidermis of brinjal plants. The present results concur with the observation of Kawaguchi et al. (2008) and reflect that brinjal can have an acceptance of $30 \%$ DC. Several parameters including the presence of metal and nutrient contents and enrichment factor did not provide accurate information for what might be the cause to provide maximum yield from 20 to $30 \%$. However SEM studies reveal the fact that though physical stress could be expected, it was desirable to study the ultra structure of the leaf stomata as a possible indicator for identifying stress mechanism in the plant. The stomata opening in leaves of plants grown in $30 \%$ DC compared to plants grown in soil, show a reduction of $19.8 \%$ (Table 3). Gupta and Bhatnagar (2015) corroborate the findings of this study, reporting that stomatal size reduced at higher concentrations of arsenic contamination with increase in frequency of arrested, fused and abnormal stomata. The closing of stomata is a fundamental process in the plant's capacity to maintain plant water status under conditions of low soil moisture content and high evaporative demand.

\section{Conclusions}

Research on palm industry waste utilization has been focusing on value addition to waste generated from the palm oil industry. Apart from POME and EFB, DC also causes stress on the ecosystem if improperly disposed as evidenced by its high acidity. Any cost involving value addition to DC would only add to the burden on the industry unless the value added product is ecologically sustainable and economically viable. DC has always been 
Table 3 Average cell size of the stomatal opening of the leaf epidermis of Brinjal plants subjected to the DC amendments

\begin{tabular}{lllcc}
\hline Plant/treatment & $\begin{array}{l}\text { Mean cell size } \\
(\text { length }) \mu \mathrm{m}\end{array}$ & $\begin{array}{l}\text { Mean Cell size } \\
(\text { width }) \mu \mathrm{m}\end{array}$ & $\begin{array}{l}\text { Mean cell } \\
\text { area }\left(\mu \mathrm{m}^{2}\right)\end{array}$ & $\begin{array}{l}\% \text { Reduction in area } \\
\text { from } 0 \text { to 30\% }\end{array}$ \\
\hline Brinjal 0\% & $36.3 \pm 0.02$ & $21.3 \pm 0.03$ & $773.2 \pm 0.02$ \\
$10 \%$ & $46.0 \pm 0.02$ & $26.0 \pm 0.04$ & $1196 \pm 0.02$ & $968 \pm 0.02$ \\
$20 \%$ & $44.0 \pm 0.01$ & $22.0 \pm 0.03$ & $153.2 \pm 0.02$ & $19.8 \pm 0.01$ \\
$30 \%$ & $24.1 \pm 0.01$ & $6.35 \pm 0.03$ & & \\
\hline
\end{tabular}

considered as a pollutant and the present investigation reveals that a moderate application of DC at 10-20\% directly into soil can assist as a fertilizer and promote growth. This is due to the tolerance limit of brinjal plants even though they thrive in low $\mathrm{pH}$ and high nutrient concentrations. The SEM pictures reveal a closure in the stomatal opening at $30 \%$ DC. Vegetable crops have been preferred because Malaysian farmers predominantly grow vegetables on raised beds. This provides easy facilitation for the farmers to mix DC with the raised bed soil thereby reducing the economic burden on the industry at the same time serving as an excellent technology for the closure of the loop of Palm oil agricultural technology where the organic matter from the plant goes back into the soil as an organic amendment.

Acknowledgments Asha Embrandiri would like to extend her gratitude to Universiti Sains Malaysia under the RUI [1001/PTEKIND/811254] grant scheme for their funding.

Open Access This article is distributed under the terms of the Creative Commons Attribution 4.0 International License (http://creative commons.org/licenses/by/4.0/), which permits unrestricted use, distribution, and reproduction in any medium, provided you give appropriate credit to the original author(s) and the source, provide a link to the Creative Commons license, and indicate if changes were made.

\section{References}

Adjei-Nsiah S, Obeng CB (2013) Effect of palm bunch ash application on soil and plant nutrient composition and growth and yield of garden eggs, pepper and okra. Int J Plant Soil Sci 2(1):1-15. doi:10.9734/IJPSS/2013/2039

Allen SE, Grimshaw HM, Rowland AP (1986) Chemical analysis. In: Moore PD, Chapman SB (eds) Methods in plant ecology. Blackwell Scientific Publication, Oxford, pp 285-344

Alloway BJ, Jackson AP, Morgan H (1991) The behavior of heavy metals in sewage sludge amended soils. Sci Total Environ 100:151-176

Assmann SM, Wang XQ (2001) From milliseconds to millions of years: guard cells and environmental responses. Curr Opin Plant Biol 4:421-428

Ciamporova M, Mistrik I (1993) The ultrastructural response of root cells to stressful conditions. Environ Exp Bot 33:11-26

Embrandiri A, Singh RP, Ibrahim MH (2013) Biochemical, morphological and yield responses of lady's finger plants to varying ratios of decanter cake application as a bio-fertilizer. Int J Recyc Org Waste Agric (IJROWA). 2(7):1-6. doi:10.1186/2251-7715-2-7
Embrandiri A, Quaik S, Rupani PF, Srivastava V and Singh P (2015) Sustainable utilization of oil palm wastes: opportunities and challenges. In: Singh R, Sarkar A (eds) Waste management: challenges, threats and opportunities. Nova Science Publishers, pp 217-232

Ekutudo MM, Nwaukwu IA, Habila S (2011) The effects of saw dust and goat dung supplements on the yield of okro (Abelmoschus esculentus L. Moench) in diesel oil contaminated soil. J Res For Wildl Enviro 3(2): 43-50

Gupta P, Bhatnagar AK (2015) Spatial distribution of arsenic in different leaf tissues and its effect on structure and development of stomata and trichomes in mung bean, Vigna radiata (L.) Wilczek. Environ Exp Bot 109:12-22. doi:10.1016/j.colsurfb. 2015.08.025

Kawaguchi M, Taji A, Backhouse D, Oda M (2008) Anatomy and physiology of graft incompatibility in solanaceous plants. J Hortic Sci Biotechnol 83(5):581-588. doi:10.1080/14620316. 2008.11512427

Kelepsei S, Nikos G, Tzortzakis (2009) Olive mill wastes-a growing medium component for seedling and crop production of lettuce and chicory. Int J Veg Sci 15:325-329

Kisku GC, Barman SC, Bhargava SK (2000) Contamination of soil and plants with potentially toxic elements irrigated with mixed industrial effluents and its impact on the environment. Water Air Soil Pollut 120:121-137 1023/A:1005202304584

Liew WL, Kassim MA, Muda K, Loh SK, Affam AC (2015) Conventional methods and emerging wastewater polishing technologies for palm oil mill effluent treatment: a review. J Environ Manage 149:222-235. doi:10.1016/j.jenvman.2014.10.016

Lim PN, Wu TY, Clarke C, Nik Daud NN (2015) A potential bioconversion of empty fruit bunches into organic fertilizer using Eudrilus eugeniae. Int $\mathbf{J}$ Environ Sci Technol 12(8):2533-2544. doi:10.1007/s13762-014-0648-2

Lim SL, Wu TY, Clarke C (2014) Treatment and biotransformation of highly polluted agro-industrial wastewater from a palm oil mill into vermicompost using earthworms. J Agric Food Chem 62(3):691-698. doi:10.1021/jf404265f

Lorestani B, Cheraghi M, Yousefi N (2011) Phytoremediation potential of native plants growing on a heavy metals contaminated soil of copper mine in Iran. World Acad Sci Eng Technol 53(2011):377-382

Mehes-Smith M, Nkongolo KK, Narendrula R, Cholewa E (2013) Mobility of heavy metals in plants and soil: a case study from a mining region in Canada. Am J Environ Sci. 9(6):483-493. doi:10.3844/ajessp.2013.483.493

Nation JL (1983) Hexamethyldisilazane procedure. Stain Technol 58(6):347-351

Ndaeyo NU, Ikeh AO, Nkeme KK, Akpan EA, Udoh EI (2013) Growth and Foliar yield responses of waterleaf (Talinum triangulare Jacq) to complementary application of organic and inorganic fertilizers in a ultisol. Am J Exp Agric 3(2):324-335. doi:10.9734/AJEA/2013/2599

Ngole VM (2011) Using soil heavy metal enrichment and mobility factors to determine potential uptake by vegetables. Plant Soil Environ 57(1):75-80 
Singh RP (2008) Land application of sewage sludge: appraisal of potential effects on plants. PhD Dissertation, Banaras Hindu University

Singh RP, Agrawal M (2009) Use of sewage sludge as fertilizer supplement for Abelmoschus esculentus plants: physiological, biochemical and growth responses. Int J Environ Waste Manage 3:91-106

Singh RP, Ibrahim MH, Esa N, Iliyana MS (2010) Composting of waste from palm oil mill: a sustainable waste management practice. Rev Environ Sci Biotechnol 9:331-344
Singh RP, Rupani PF, Singh A, Embrandiri A, Ibrahim MH (2012) Towards sustainable palm oil production: minimizing the environmental damage from oil palm processing. Book Chapter: Waste Management: New Research. Nova Publications. pp 421-440

Zwart R (2013) Opportunities and challenges in the development of a viable Malaysian palm oil biomass industry. J Oil Palm Environ. 4:41-46. doi:10.5366/jope.2013.05 